\title{
Coupled climate impacts of the Drake Passage and the Panama
} Seaway

\section{Journal Article}

\section{Author(s):}

Yang, Simon; Galbraith, Eric; Palter, Jaime B.

Publication date:

2014-07

Permanent link:

https://doi.org/10.3929/ethz-b-000087226

Rights / license:

In Copyright - Non-Commercial Use Permitted

Originally published in:

Climate Dynamics 43(1-2), https://doi.org/10.1007/s00382-013-1809-6 


\title{
Coupled climate impacts of the Drake Passage and the Panama Seaway
}

\author{
Simon Yang $\cdot$ Eric Galbraith $\cdot$ Jaime Palter
}

Received: 19 February 2013/Accepted: 15 May 2013/Published online: 25 May 2013

(C) Springer-Verlag Berlin Heidelberg 2013

\begin{abstract}
Tectonically-active gateways between ocean basins have modified ocean circulation over Earth history. Today, the Atlantic and Pacific are directly connected via the Drake Passage, which forms a barrier to the time-mean geostrophic transport between the subtropics and Antarctica. In contrast, during the warm early Cenozoic era, when Antarctica was ice-free, the Drake Passage was closed. Instead, at that time, the separation of North and South America provided a tropical seaway between the Atlantic and Pacific that remained open until the Isthmus of Panama formed in the relatively recent geological past. Ocean circulation models have previously been used to explore the individual impacts of the Drake Passage and the Panama Seaway, but rarely have the two gateways been considered together, and most explorations have used very simple atmospheric models. Here we use a coupled ocean-iceatmosphere model (GFDL's CM2Mc), to simulate the impacts of a closed Drake Passage both with and without a Panama Seaway. We find that the climate response to a closed Drake Passage is relatively small when the Panama Seaway is absent, similar to prior studies, although the coupling to a dynamical atmosphere does increase the temperature change. However, with a Panama Seaway, closing
\end{abstract}

S. Yang $(\bowtie) \cdot$ E. Galbraith

Department of Earth and Planetary Sciences, McGill University,

3450 University St., Montreal, QC H3A 2A7, Canada

e-mail: simon.yang@mail.mcgill.ca

S. Yang

Department of Environmental Systems Science, ETH Zurich,

Universitätstr. 16, 8092 Zurich, Switzerland

J. Palter

Department of Atmospheric and Oceanic Sciences,

McGill University, 805 rue Sherbrooke Ouest,

Montreal, QC H3A 0B9, Canada
Drake Passage has a much larger effect, due to the cessation of deep water formation in the northern hemisphere. Both gateways alter the transport of salt by ocean circulation, with the Panama Seaway allowing fresh Pacific water to be imported to the North Atlantic, and the Drake Passage preventing the flow of saline subtropical water to the circumAntarctic, a flow that is particularly strong when the Panama Seaway is open. Thus, with a Panama Seaway and a closed Drake Passage, the Southern Ocean tends to be relatively salty, while the North Atlantic tends to be relatively fresh, such that the deep ocean is ventilated from the circum-Antarctic. Ensuing changes in the ocean heat transport drive a bipolar shift of surface ocean temperatures, and the Intertropical Convergence Zone migrates toward the warmer southern hemisphere. The response of clouds to changes in surface ocean temperatures amplifies the climate response, resulting in temperature changes of up to $9{ }^{\circ} \mathrm{C}$ over Antarctica, even in the absence of land-ice feedbacks. These results emphasize the importance of tectonic gateways to the climate history of the Cenozoic, and support a role for ocean circulation changes in the glaciation of Antarctica.

Keywords Eocene-Oligocene transition - Drake Passage . Panama Seaway · Gateway · Antarctic Circumpolar Current - Ocean circulation · Heat transport - Paleoclimate

\section{Introduction}

The role of tectonically-active gateways between ocean basins is important for understanding both ocean circulation and climate history. One intensively studied gateway is the Drake Passage, which plays a central role in closing the Meridional Overturning Circulation (MOC) which transports heat and chemicals in the ocean (see Marshall and 
Table 1 Non exhaustive list of past simulations studying the effect of the Drake Passage on climate and ocean circulation

\begin{tabular}{llllll}
\hline Author & Model & Atmosphere & Ocean & Bathymetry $^{\text {pCO }_{2}}$ \\
\hline Mikolajewicz et al. (1993) & Hamburg-FC & None & $3.5^{\circ} \times 3.5^{\circ} \times 11^{\circ}$ & Modern & - \\
Toggweiler and Samuels (1995) & GFDL MOM-FC & None & $4.5^{\circ} \times 3.75^{\circ} \times 12$ & Modern & Preindustrial \\
Toggweiler and Bjornsson (2000) & GFDL MOM (WPM) & EBM $^{\text {c }}$ & $4.5^{\circ} \times 3.75^{\circ} \times 12$ & Modern & Preindustrial \\
Nong et al. (2000) & NCAR CSM-FC & None & $3.6^{\circ} \times 1.8-3.4^{\circ} \times 25$ & Modern & Preindustrial \\
Sijp and England (2004) & Uvic & EBM & $3.6^{\circ} \times 1.8^{\circ} \times 19$ & Modern & Preindustrial \\
Sijp and England (2005) & Uvic & EBM & $3.6^{\circ} \times 1.8^{\circ} \times 19$ & Modern & Preindustrial \\
Sijp and England (2009) & Uvic & EBM & $3.6^{\circ} \times 1.8^{\circ} \times 19$ & Modern & Preindustrial \\
Sijp et al. (2009b) & Uvic & EBM & $3.6^{\circ} \times 1.8^{\circ} \times 19$ & Modern & Preindustrial \\
Zhang et al. (2010) & FOAM & $4.5^{\circ} \times 7.5^{\circ}$ & $2.8^{\circ} \times 1.4^{\circ} \times 24$ & Eocene & 2,240 ppm \\
Zhang et al. (2011) & FOAM & $4.5^{\circ} \times 7.5$ & $2.8^{\circ} \times 1.4^{\circ} \times 24$ & Eocene & 2,240 ppm \\
Cristini et al. (2012) & LSGEBM/COSMOS & None/3.75 & $3^{\circ} \times 22 / 3^{\circ} \times 1.8^{\circ} \times 40$ & Modern & Preindustrial \\
Lefebvre et al. (2012) & FOAM & $4.5^{\circ} \times 7.5$ & $2.8^{\circ} \times 1.4^{\circ} \times 24$ & Eocene & $280,420,560$, \\
& & & & 700,840 ppm \\
Current study & CM2MC & $3^{\circ} \times 3.75$ & $2.5^{\circ} \times 0.6-3.39^{\circ} \times 28$ & Modern & Preindustrial
\end{tabular}

Specifics about the model used and boundary condition are listed

${ }^{\text {a }}$ Flux correction are applied

b Water Planet model

${ }^{c}$ Energy Balance Model

${ }^{\mathrm{d}}$ COSMOS is initialized and restored to LSGEBM, a zonally averaged model of intermediate complexity

Speer 2012 for a detailed review). The land-free latitudinal band of the Drake Passage enables the southern westerlies to drive the strongest current in the world, the Antarctic Circumpolar Current (ACC), along the southern margin of which waters upwell from great depth. However, this was not always the case. The Drake Passage was completely closed until $50 \mathrm{Ma}$, necessitating a very different global oceanic circulation and hence, climate.

The Drake Passage opened in fits and starts between 50 and $20 \mathrm{Ma}$ (Lawver and Gahagan 2003; Livermore et al. 2005; Livermore et al. 2007). Neodymium measurements from fish teeth (Scher and Martin 2006; Scher and Martin 2008) suggest a complex history of deep water masses in the South Atlantic through the Eocene and Oligocene, while tectonic reconstructions (Lagabrielle et al. 2009) suggest a rapid deepening of the Drake Passage ca. 33-35 Ma, prompting the suggestion that the establishment of the ACC at this time was behind the abrupt cooling and inception of Antarctic ice sheet at the Eocene-Oligocene boundary, 34 Ma (Tigchelaar et al. 2011). Kennett (1977) was the first to suggest a link between gateway changes and the Eocene-Oligocene boundary cooling, stating that the formation of the ACC would have thermally insulated Antarctica, enabling the growth of its ice sheet. It has been suggested that the formation of North Atlantic Deep Water (NADW) also began at the Eocene-Oligocene boundary (Via and Thomas 2006), perhaps facilitated by both the subsidence of the Greeland-Scotland Ridge near this time (Davies et al. 2001), as well as the formation of the
circum-Antarctic channel (Mikolajewicz et al. 1993; Toggweiler and Samuels 1995; Dijkstra et al. 2003)

Prompted by these possibilities, the climate response to a closed Drake Passage has been explored with a variety of general circulation models (see Table 1). These models vary in complexity, including ocean-only, ocean with simple atmosphere, and more recently, coupled oceanatmosphere models. Using the UVic model, which has a two-dimensional non-dynamical atmosphere, Sijp and England (2004) found that, similar to most works, closing the Drake Passage caused North Atlantic Deep Water to stop forming, while a strong southern overturning developed and air temperatures warmed zonally by as much as $3.7^{\circ} \mathrm{C}$ over the Southern Ocean. However, Sijp and England (2009) revisited their study by using larger moisture diffusion coefficients, testing a key uncertainty with their idealized atmosphere, and found that with the improved moisture transport parameters, the Drake Passage had little impact on NADW. Thus, from these studies one might conclude that the development of the Drake Passage had a relatively modest impact on climate.

However, these studies did not explicitly test the role of a second tectonically-active gateway between the Atlantic and Pacific oceans. The Panama Seaway only started restricting $\sim 14$ million years ago, providing, until then, a tropical gateway. Although some recent simulations have included this (and other) tectonic changes relevant to the early Cenozoic (e.g. Zhang et al. 2010, 2011; Lefebvre et al. 2012), the superposition of multiple tectonic changes with 
additional changes in boundary conditions, such as poorlyconstrained changes of atmospheric carbon dioxide, can obscure the specific effects of the gateways. Furthermore, subtle features of the geometry can have unrecognized effects when attempting detailed tectonic reconstructions. For these reasons, the effects of gateways themselves can be most clearly assessed in simple experiments for which only the gateways are changed while all else is held equal.

Here we use a recently-developed Earth System Model, CM2Mc, to look at changes in oceanic circulation resulting from the closure of Drake Passage with and without a Panama Seaway, in a series of 3000-year simulations. We then investigate the mechanisms behind the simulated changes, particularly the role of salinity in setting the locations of deep water sinking. Climate impacts are then investigated through changes in heat transport and atmospheric circulation, focusing on the Hadley circulation and the radiative balance at the top of the atmosphere. The purpose is not to simulate any specific period of Earth history, but rather to examine the mechanisms by which these two important gateways influence the climate system.

\section{Model and simulations}

\subsection{The model}

All simulations were carried out using CM2Mc (Galbraith et al. 2011), a three-degree version of NOAA GFDL's coupled climate model, CM2.1 (Delworth et al. 2006), with the ocean component incorporating many of the updates that are now included in GFDL's Earth System Model, ESM2M (Dunne et al. 2012). The Modular Ocean Model MOM4p1 is integrated with a grid of horizontal resolution of $2.5^{\circ}$ varying in the meridional dimension according to latitude with finest resolution at the equator of $0.6^{\circ}$. It includes 28 vertical levels defined by pressure, the top eight being $10 \mathrm{db}$ thick and the lower levels increasing in thickness with depth. Partial bottom cells (Adcroft et al. 1997) allow realistic bathymetry. Lateral diffusion and skew diffusion of tracers along isopycnals are represented using the parameterization of Gent and Mcwilliams (1990) with a spatially varying diffusion coefficient, $\mathrm{A}_{G M}$. The model uses a background vertical diffusivity of $0.1 \times 10^{-4} \mathrm{~m}^{2} \mathrm{~s}^{-1}$ with intense vertical mixing near rough topography that varies as a function of stratification (Simmons et al. 2004).

The ocean circulation model is coupled to a fully dynamic 3D atmosphere and the GFDL thermodynamicdynamic sea ice model (SIS). The atmospheric model is the GFDL Atmospheric Model 2 (AM2) with a latitudinal resolution of $3^{\circ}$, a longitudinal resolution of $3.75^{\circ}$ and 24 vertical levels. It has an explicit representation of the diurnal cycle of solar radiation, a 3-level cloud parameterization and a full hydrological cycle. The model does not simulate dynamic vegetation cover on land, nor land-based ice sheets, which have not yet been incorporated in global ocean-atmosphere models. The model does not apply any flux adjustments, enabling it to simulate atmosphere-ocean-sea ice feedbacks including salinity and temperature feedbacks in the ocean. Despite this, the circulation is very similar to that of the GFDL CM2.1 model (Dunne et al. 2012), which is generally highly ranked among coupled models, and which had the best simulation of the Southern Westerlies and Antarctic Circumpolar Current according to the metrics of Russell et al. (2006). As such, it is a particularly appropriate model to use for studying the Drake Passage. The ocean model includes an 'ideal age' tracer, which is set to zero at the surface layer, increases by one year per model year in all other grid cells, and is subject to mixing and advection by the ocean circulation.

\subsection{Simulations}

We perform two pairs of simulations to investigate the role of the Drake Passage on ocean circulation and climate. In the first pair, we test the effect of the Drake passage without a Panama Seaway. In the second pair of simulations, the Panama Seaway is open. In the first set, the absence of a Panama Seaway allows for comparison with previous studies. The presence of a Panama Seaway in the second set provides a more geologically relevant simulation of the closure of the Drake Passage. By including all four possible gateway configurations (including the modern case), this suite of simulations allows us to unambiguously isolate the effect of each gateway on ocean circulation and climate. The Drake passage is closed by simply inserting a land bridge between the southern tip of South America and the northern Antarctic peninsula while the Panama Seaway is opened by changing four land cells to 2,000 $\mathrm{m}$ deep ocean cells. The bathymetries used at each gateway are shown in Fig. 1. All other boundary conditions such as $\mathrm{pCO}_{2}$, orbital configurations, land cover and ice sheets are kept at preindustrial levels. Each simulation is integrated for 3,000 years and analyses are made using the temporal average of the final hundred years.

\section{The effect of the Drake Passage on the global overturning circulation}

\subsection{Without a Panama Seaway}

Many previous studies aimed to isolate the influence of the Drake Passage on global climate by closing the Drake Passage with a land bridge and keeping all other boundary 
Fig. 1 Bathymetric boundary conditions used in the experiments. Detailed insets show the Drake Passage, open and closed, and the Panama Seaway, open and closed

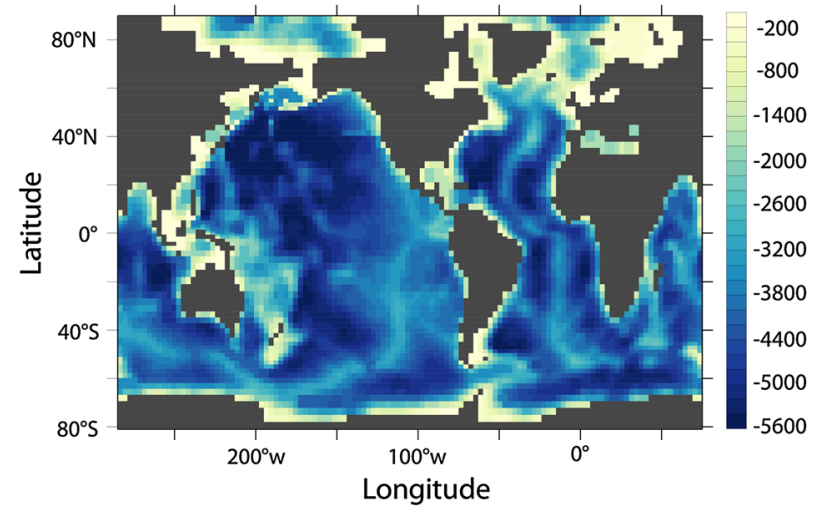

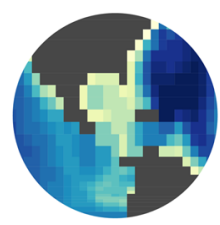
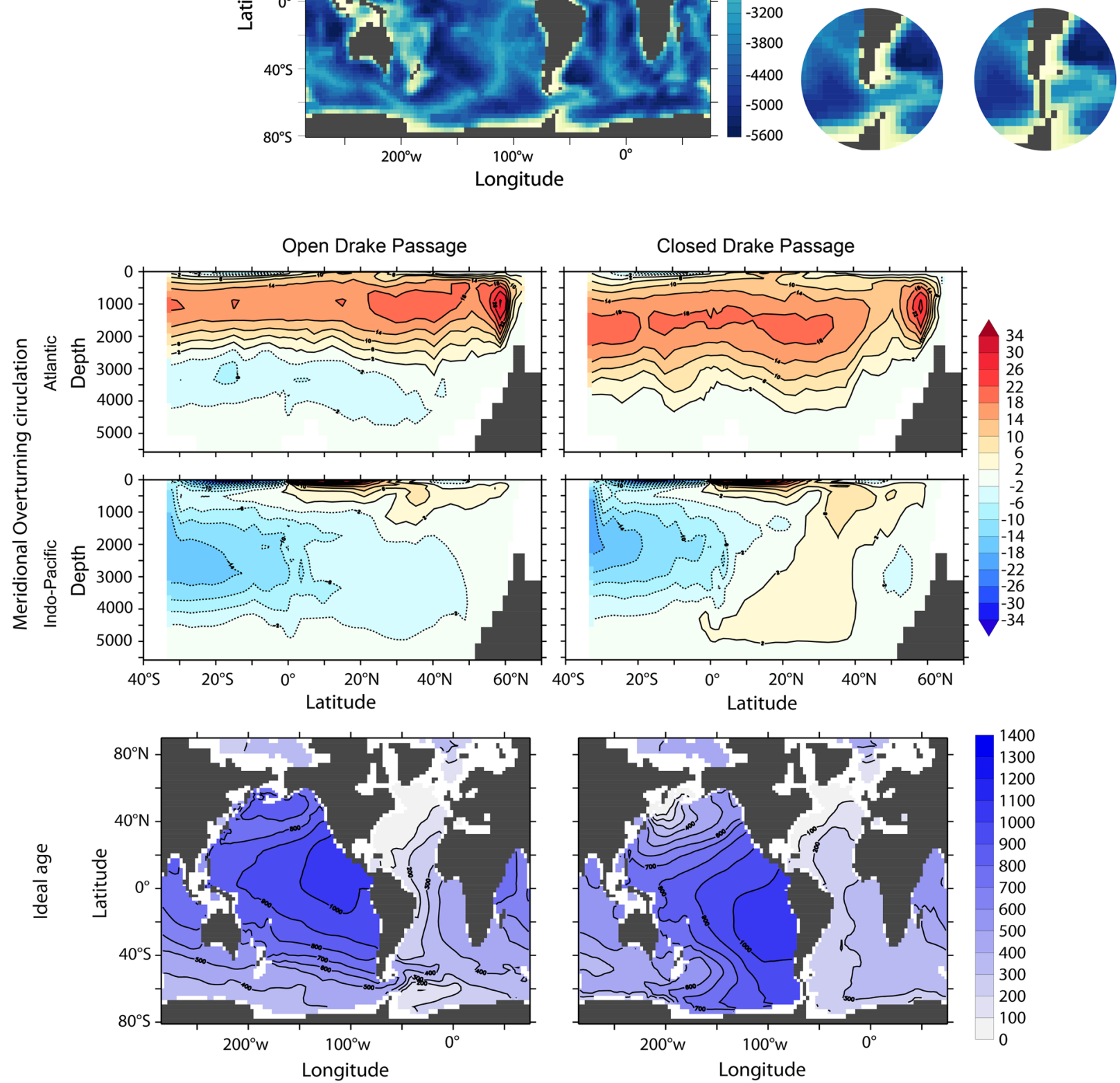

Fig. 2 Global ocean circulation without a Panama Seaway. The top two panels show the Atlantic and Indo-Pacific overturning streamfunctions, while the bottom panels show ideal age at 2,000 m, for simulations with an open Drake Passage (left) and a closed Drake

conditions as at present. Here we present the results of a similar experiment for comparison with these studies, using our fully coupled atmosphere-ocean-ice model.

Figure 2 shows global overturning and ideal age for both open and closed Drake Passage configurations. In the present-day configuration, the model reproduces the

Passage (right). Overturning streamfunctions are in $\mathrm{Sv}\left(10^{9} \mathrm{~kg} \mathrm{~s}^{-1}\right)$, where orange indicates overturning in a clockwise sense, as viewed looking towards the west, and blue indicates counter-clockwise

observed inter-hemispheric overturning circulation, with formation of both NADW and AABW. Unlike many prior experiments with simpler models (Mikolajewicz et al. 1993; Nong et al. 2000; Sijp and England 2004), with the Drake Passage closed, NADW does not shut down. Rather, the circulation is dominated at all depths by northern 
overturning in the Atlantic with the suppression of the lower AABW cell. In addition, deep ventilation is established in the North Pacific, although this remains restricted to the northern hemisphere.

Among the prior studies mentioned, none included a dynamic atmospheric circulation models that could have responded to changes in ocean circulation, and the advection of moisture was represented with simple diffusion parameterizations. However, Sijp and England (2009) found a surprisingly similar oceanic circulation to that described here, after modifying the moisture transport parameterization of their energy balance model. Their modifications increased the moisture transport by southern midlatitude storms in order to be closer to observations, and under these conditions, the AMOC continued when Drake Passage was closed. It would appear that a more realistic moisture transport moves sufficient freshwater to maintain a robust AMOC whether or not the Drake Passage is open, when all other boundary conditions are as in the pre-industrial.

\subsection{With a Panama Seaway}

With a Panama Seaway and the Drake Passage open, the global overturning is similar to the modern configuration, with both northern and southern overturning cells. Although the island rule (Godfrey 1989) would predict a net wind-driven flow from the Atlantic to the Pacific, this only applies to a homogenous fluid of uniform depth, which is not the case here. Instead, the sea surface height gradient between the two basins results in a flow that is opposite, from the Pacific to the Atlantic, consistent with the results of Schneider and Schmittner (2006). On average, a total of $18 \mathrm{~Sv}$ is transported from the Pacific to the

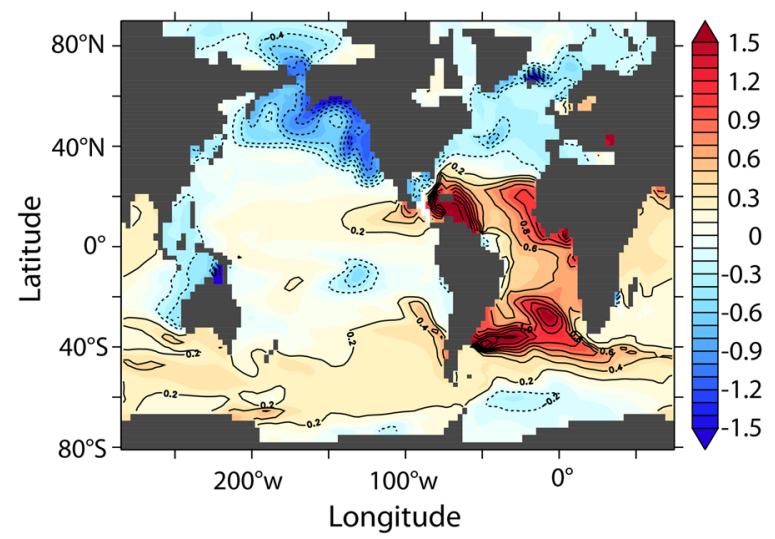

Fig. 3 The effect of the Panama Seaway on salinity, and inter-basin transports. The left panel shows the sea surface salinity with a Panama Seaway minus the sea surface salinity with no Panama Seaway in $\mathrm{g} \mathrm{kg}^{-1}$. The right panel shows the cumulative transports through the
Atlantic (Fig. 3). The Gulf Stream is therefore sourced with a mixture of Atlantic subtropical waters as well as fresher subtropical Pacific waters. This results in a freshening of the North Atlantic (Fig. 3) and a minor reduction in the AMOC (Table 2). Also, with NADW being fresher, less salt is transported in the deep ocean resulting in the excess salt accumulating in the surface subtropical Atlantic.

As seen in Table 2, the appearance of a Panama Seaway provides a shortcut from the Pacific to the Atlantic, eliminating the need for Pacific to Atlantic exchange to travel via the Indonesian through-flow and the Aghulas Leakage around the southern tip of Africa (also shown by Schneider and Schmittner 2006). In the absence of a Panama Seaway, the longer circulation pathway through the Indian Ocean transports salty Indian Ocean water into the Atlantic and densifies the South Atlantic. Therefore, the Southern Overturning cell is on denser and deeper layers than when direct exchange is cut off by a closed Panama Isthmus. Furthermore, in the closed-Panama case, the shallow limb of the deep Southern Overturning cell is almost entirely below $1,000 \mathrm{~m}$, and is thus not included in the Brazil Current (defined here as the integrated flow above $1,000 \mathrm{~m}$ between $55^{\circ} \mathrm{W}$ and $42^{\circ} \mathrm{W}$ at $32^{\circ} \mathrm{S}$ ). The opening of a Panama Seaway freshens the Atlantic and shoals the depth of the southern overturning circulation, so that the shallow southward return flow occurs largely above $1,000 \mathrm{~m}$ and is included in our accounting of the Brazil Current (Table 2).

In contrast to the modest AMOC weakening found here, early studies (Maier-Reimer et al. 1990; Mikolajewicz et al. 1993; Mikolajewicz and Crowley 1997; Murdock et al. 1997) found that, upon opening the Panama Seaway, a flow of fresher Pacific water to the Atlantic led to a cessation of the AMOC and therefore reduced poleward

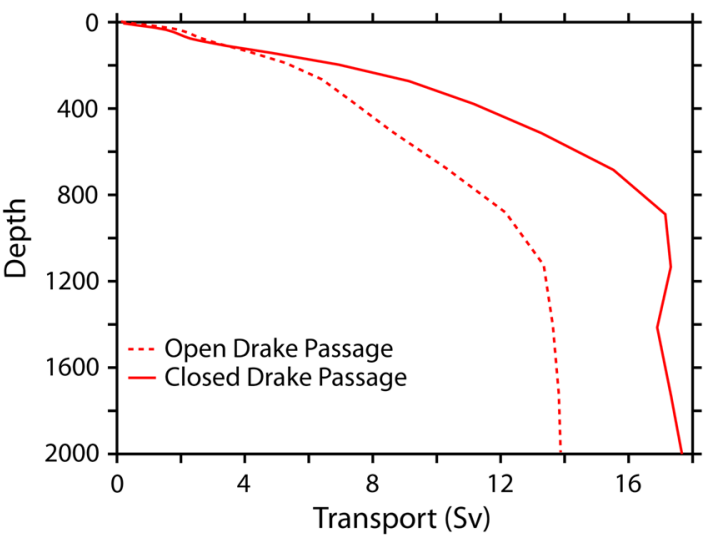

Panama Seaway, with an open Drake Passage (dashed line) and a closed Drake Passage (solid line) in $\mathrm{Sv}\left(10^{9} \mathrm{~kg} \mathrm{~s}^{-1}\right)$. Positive transports are from Pacific to Atlantic 
Table 2 Various transports in Sverdrups $\left(10^{6} \mathrm{~m}^{3} \mathrm{~s}^{-1}\right)$

\begin{tabular}{|c|c|c|c|c|c|c|c|c|}
\hline Simulation & SMOC & NMOC & Gstrm & $\mathrm{BraCu}$ & $\mathrm{BrSt}$ & ITF & Panama & ACC \\
\hline \multicolumn{9}{|c|}{ Closed Panama Seaway } \\
\hline Open DP & 19.3 & 23.6 & 41.1 & 4.8 & 1.2 & 13.5 & - & 167.7 \\
\hline Closed DP & 3.3 & 21.7 & 32.9 & 0.7 & 1.7 & 16.5 & - & - \\
\hline \multicolumn{9}{|c|}{ Open Panama Seaway } \\
\hline Open DP & 18.6 & 19.9 & 41.7 & 26.10 & 1.5 & 2.6 & 17.8 & 152.2 \\
\hline Closed DP & 29.6 & 0.0 & 26.6 & 46.5 & 0.6 & 8.2 & 13.9 & - \\
\hline
\end{tabular}

SMOC is defined as the maximum anticlockwise transport at $30^{\circ} \mathrm{S}, \mathrm{NMOC}$ as the maximum clockwise transport at $40^{\circ} \mathrm{N}$

Gstrm stands for the total Gulf stream transport between $70^{\circ} \mathrm{W}$ and $82^{\circ} \mathrm{W}$ at $27^{\circ} \mathrm{N}$ integrated from $\mathrm{z}=0$ to $1,000 \mathrm{~m}$ (northward positive), BraCu for the total Brazil current transport between $55^{\circ} \mathrm{W}$ and $42^{\circ} \mathrm{W}$ at $32^{\circ} \mathrm{S}$ integrated from $\mathrm{z}=0$ to $1,000 \mathrm{~m}$ (southward positive), BrSt for the total transport through the bering straight, ITF to the total Indonesian through-flow transport (Pacific to Indian positive), Panama for the total Panama gateway transport (Pacific to Atlantic positive), ACC for the total transport trough the Drake Passage

heat transport in the Northern Hemisphere. These studies, again, used either ocean-only models or simple representations of an atmosphere along with simple ocean mixing parameterizations and flux corrections. Our results are consistent with later studies (Nisancioglu et al. 2003; Schneider and Schmittner 2006; Lunt et al. 2008) that use newer representations of ocean mixing and some representation of an atmosphere, finding that significant NADW is produced even with a Panama Seaway, weakening rather than shutting down northern overturning. Thus, although it weakens the AMOC somewhat, the presence of a Panama Seaway is also insufficient, on its own, to halt the northern overturning in this model while the Drake Passage is open.

However, the importance of the Panama Seaway increases greatly when the Drake Passage is closed. In stark contrast to the case without a Panama Seaway, this configuration shows a complete absence of an inter-hemispheric overturning driven by the North Atlantic. Instead, the large-scale overturning is dominated by waters sinking in the Southern Ocean, with a maximum of $30 \mathrm{~Sv}$ of northern transport at $30^{\circ} \mathrm{S}$ (Fig. 4, Table 2). As evident from the ideal age, the deep ocean is ventilated almost exclusively by the Southern Ocean, with insignificant deep water formation in the Northern Hemisphere. This response is evocative of neodymium measurements from fish teeth which suggest that the Eocene deep ocean was dominated by waters of southern origin (Thomas and Bralower 2003; Thomas et al. 2008). Associated with the cessation of the AMOC and onset of strong southern overturning is a weakening of the Gulf Stream (41-25 Sv) and a strengthening of the net surface $(0-1,000 \mathrm{~m})$ southward flow east of Brazil (26-40 Sv). The extremely strong southward transport east of Brazil in this simulation, which was absent in the runs without a Panama Seaway, carries warm subtropical waters to the Antarctic. This has a large effect on the climate response, discussed below. But first, we address the mechanisms underlying the simulated changes in ocean circulation.

\subsection{Changes in the deep water return paths}

In the modern ocean, the return flow of deep water to the surface can be viewed as divided between low-latitude upwelling through diapycnal mixing and wind driven upwelling in the Southern Ocean (Gnanadesikan 1999; Kuhlbrodt et al. 2007; Nikurashin and Vallis 2012). It has been suggested that the absence of the return flow provided by the deep wind driven upwelling of the Southern Ocean would inevitably result in the shutdown of northern overturning (Toggweiler and Bjornsson 2000). Here we show that this is not necessarily the case, with low-latitude upwelling providing a strong enough return route to sustain significant northern overturning with a closed Drake Passage and no Panama Seaway.

Table 3 shows simulated zonally and vertically integrated northward transports through two sections $\left(30^{\circ} \mathrm{S}\right.$ and $40^{\circ} \mathrm{N}$ ) below $\sigma_{2}=36.5 \mathrm{~kg} \cdot \mathrm{m}^{-3}$ (with a mean global depth of $1,010 \mathrm{~m}$ ) as well as their differences. Conservation of mass requires that meridional differences in the transport below $\sigma_{2}=36.5 \mathrm{~kg} \cdot \mathrm{m}^{-3}$ (an arbitrary dividing line between the shallow and deep ocean) reflect upwelling/downwelling through this same isopycnal. We will therefore refer to the difference in the transports between $30^{\circ} \mathrm{S}$ and $40^{\circ} \mathrm{N}$ and below $\sigma_{2}=36.5 \mathrm{~kg} \cdot \mathrm{m}^{-3}$ as deep low-latitude upwelling. With no Panama Seaway and an open Drake Passage (the modern configuration), a total of $13.3 \mathrm{~Sv}$ is upwelled globally at low-latitudes. This is closest to the observationally-based estimate of Lumpkin and Spear (2007) (10.1 Sv) although other estimates for low-latitude upwelling are as low as $0.2 \mathrm{~Sv}$ (ECCO) and as high as 20.1 Sv (Talley 2008) (see Table 2-Palter et al. 2010). With a closed Drake Passage, the total amount of deep low-latitude upwelling increases to $23.1 \mathrm{~Sv}$. This increase in deep low-latitude upwelling occurs in the Indo-Pacific (17.6 Sv), balancing increased northward flow of waters at $30^{\circ} \mathrm{S}$ as well as a southward flow of North Pacific deep water at $40^{\circ} \mathrm{N}$. With 

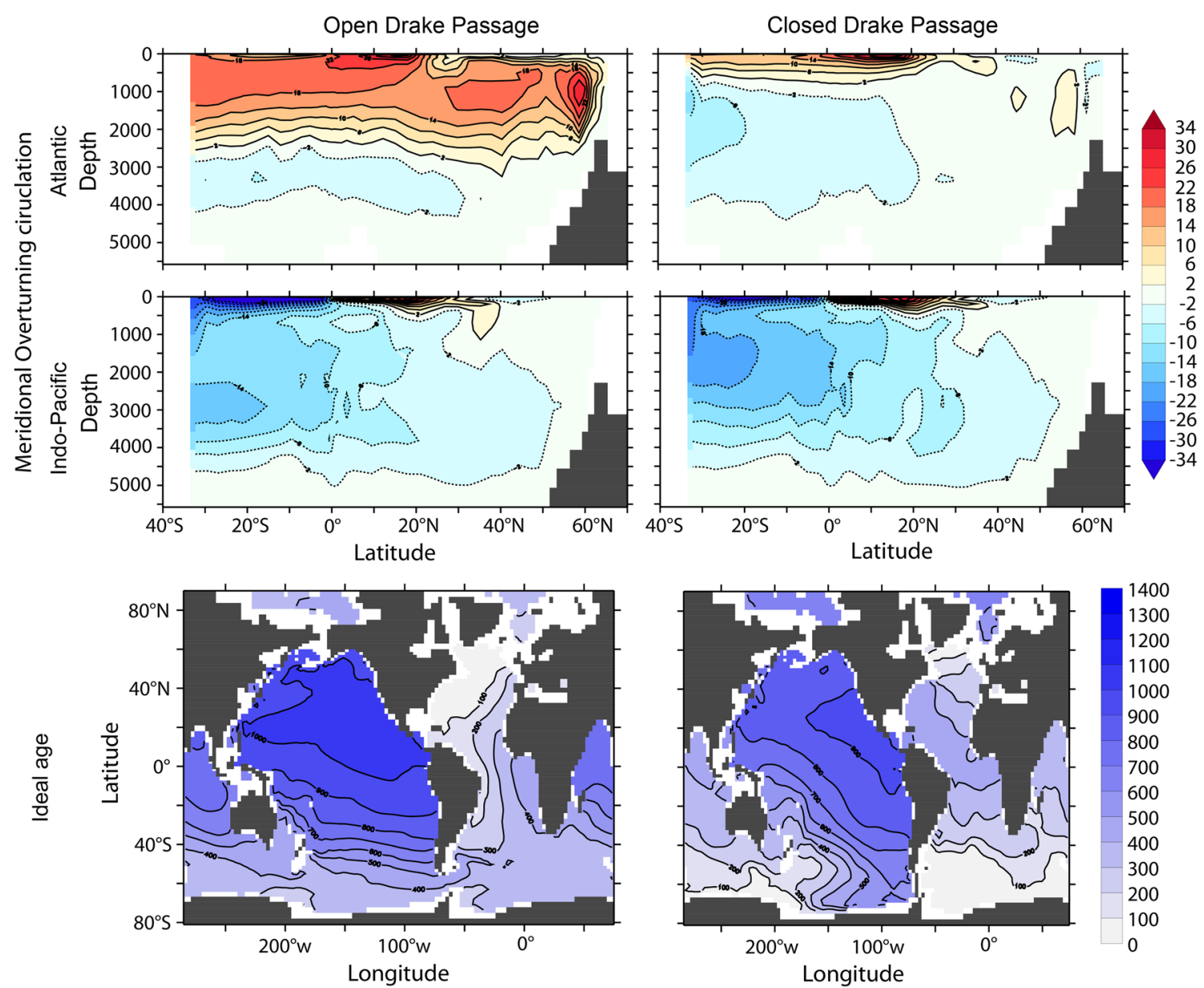

Fig. 4 Global ocean circulation with a Panama Seaway. The top four panels show the Atlantic and Indo-Pacific overturning streamfunctions, while the bottom panels show ideal age at $2,000 \mathrm{~m}$, for

simulations with an open Drake Passage (left) and a closed Drake Passage (right). Overturning streamfunctions are in $\mathrm{Sv}\left(10^{9} \mathrm{~kg} \mathrm{~s}^{-1}\right)$

Table 3 Zonally and vertically integrated northward transports below $\sigma_{2}=36.5 \mathrm{~kg} \mathrm{~m}^{-3}$ at $40^{\circ} \mathrm{N}$ and $30^{\circ} \mathrm{S}$ in Sverdrups

\begin{tabular}{lrrr}
\hline Simulation & \multicolumn{1}{c}{$T_{40 N}$} & \multicolumn{1}{l}{$T_{30 S}$} & $\Delta T$ \\
\hline Closed Panama Seaway & & & \\
Open DP & -23.5 & -10.2 & 13.3 \\
Closed DP & -20.5 & 2.6 & 23.1 \\
Open Panama Seaway & & & \\
Open DP & -20.7 & -7.1 & 13.6 \\
Closed DP & -0.6 & 13.6 & 13.0 \\
\hline
\end{tabular}

The difference between these transports $(\Delta T)$ reflects, by continuity, the upwelling across this isopycnal between $40^{\circ} \mathrm{N}$ and $30^{\circ} \mathrm{S}$, which we refer to as deep low-latitude upwelling

a Panama Seaway and an open Drake Passage, 13.6 Sv of deep low-latitude upwelling occurs, similar to the closed Panama case. With Panama Seaway open, a closed Drake Passage prevents the formation of deep water in either the North Atlantic or North Pacific. Although large volumes of deep waters are formed in the Southern Ocean (see SMOC in Table 2), most of it is recirculated in the Southern Ocean with only $13.6 \mathrm{~Sv}$ being exported northward at $30^{\circ} \mathrm{S}$ resulting in a total low-latitude upwelling of 13.0 Sv.

To summarize, without a Panama Seaway, a closed Drake Passage leads to a strong increase in low-latitude upwelling, in this model. This enhanced upwelling balances a similar overall formation of deep waters, including dense water formation in the North Atlantic and North Pacific, even in the absence of wind-driven deep upwelling in the Southern Ocean. With a Panama Seaway, a similar amount of low-latitude upwelling occurs whether or not Drake Passage is open, with the decrease/increase of Southern Ocean upwelling compensating for the decrease/ increase of North Atlantic sinking. We caution that, like all commonly-used ocean models, ours does not conserve energy in deep ocean mixing parameterizations, which may bias these results. 


\section{The role of salinity}

Causality can be difficult to attribute in a coupled model. However, the dramatic contrasts in deep ocean circulation observed here are clearly related to changes in the distribution of salinity within the ocean. Although there are changes in the surface wind fields between the four simulations, they are typically quite small; as an example, the southern westerly winds change their maximum strength and position by less than $11 \%$ and 0.3 latitudinal degrees respectively (Fig. 5). It has long been recognized that salinity plays a key role in determining whether or not convection occurs in cold, polar oceans, given that, at high latitudes, the stratification is set by salinity (Warren 1983; Broecker 1991; Carmack 2007; Ferreira et al. 2010). As shown by our simulations, the Panama Seaway and the Drake Passage together play a large role in modifying the global salinity distributions.

Figure 6 shows the simulated monthly maximum density at the sea surface in the four polar regions where deep water can form: the southern Indo-Pacific, the South Atlantic, the North Atlantic and the North Pacific. The symbols therefore describe how the temperature, salinity and density vary among the four gateway configurations in the potential deep water formation regions. Note that, because temperatures are quite low in all polar regions, the simulated range of salinity exerts an effect on density that is roughly five times as large as that of temperature.

As shown in Figs. 6 and 7, whether or not there is a Panama Seaway, the North Atlantic freshens when the Drake Passage is closed; however, the freshening is much greater with a Panama Seaway. Most interestingly, with a closed Drake Passage, the South Atlantic becomes fresher when the Panama Seaway is closed and saltier when the Panama Seaway is open, relative to the modern configuration. Thus, the density relationship between the North

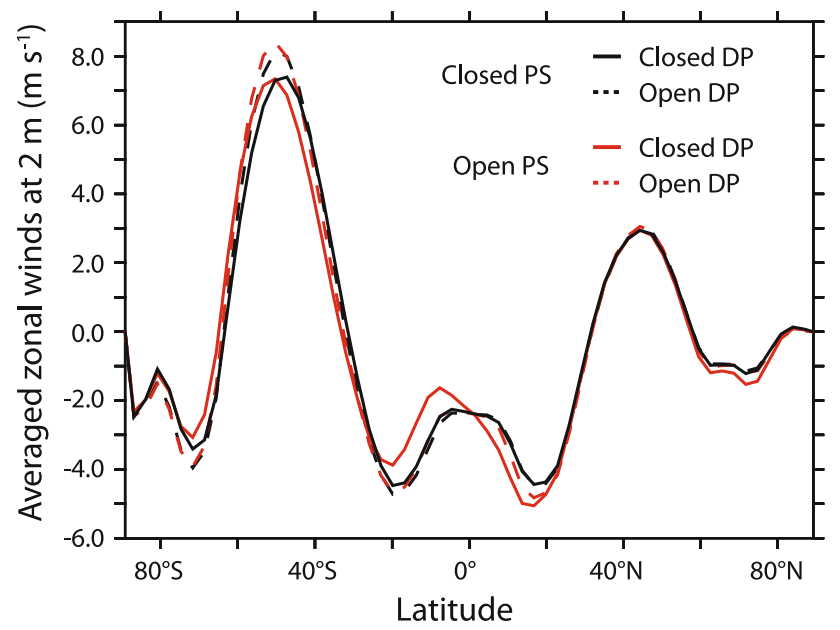

Fig. 5 Simulated zonally averaged winds at $2 \mathrm{~m}\left(\mathrm{~ms}^{-1}\right)$

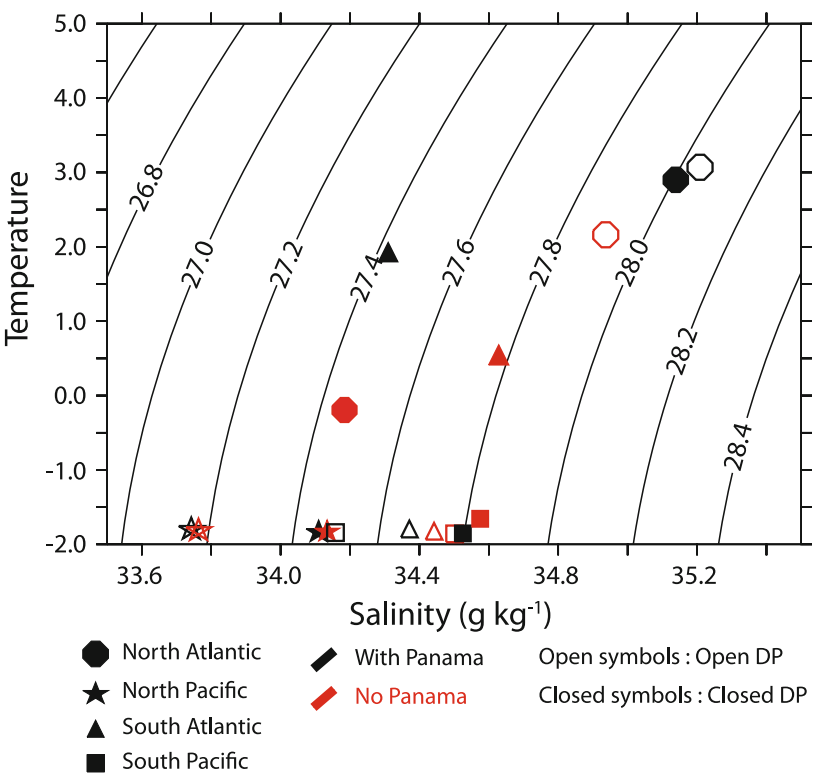

Fig. 6 Surface densities in potential deep-water formation regions. Shown are the maximum monthly-averaged densities of surface sea water at any point within the four high-latitude ocean basins. Red symbols represent the presence of a Panama Seaway while black symbols represent the absence of a Panama Seaway, and open symbols represent an open Drake Passage while filled symbols represent a closed Drake Passage

Atlantic and South Atlantic undergoes a tremendous change between the open and closed Drake Passage cases, when the Panama Seaway is present. We suggest that this is of central importance.

There are two mechanisms that change the salinity of potential deep water formation regions: change in the redistribution of salt by ocean circulation, and change in the surface freshwater budget due to precipitation minus evaporation (PME). Because regions of deep water formation tend to have relatively fresh surface waters, they receive an advective input of salt when subtropical waters are drawn in to replace the subsurface outflow of deep waters. This salinity feedback strengthens the overturning circulation by increasing the density in regions of deep water formation, a process often referred to as the Stommel salt advection feedback (Stommel 1961).

At the same time, PME varies with atmospheric circulation, moisture content and ocean temperature. Figure 8 shows differences in PME resulting from opening the Drake Passage, with and without a Panama Seaway. Without a Panama Seaway, opening Drake Passage results in a negligible change in PME, while with a Panama Seaway, there are significant changes in PME. Tropical changes in PME result from the northerly shift of the ITCZ (explained in more details in Sect. 5.3). In contrast, increased PME in the northern subtropics, particularly the North Atlantic, and decreased PME in the southern 

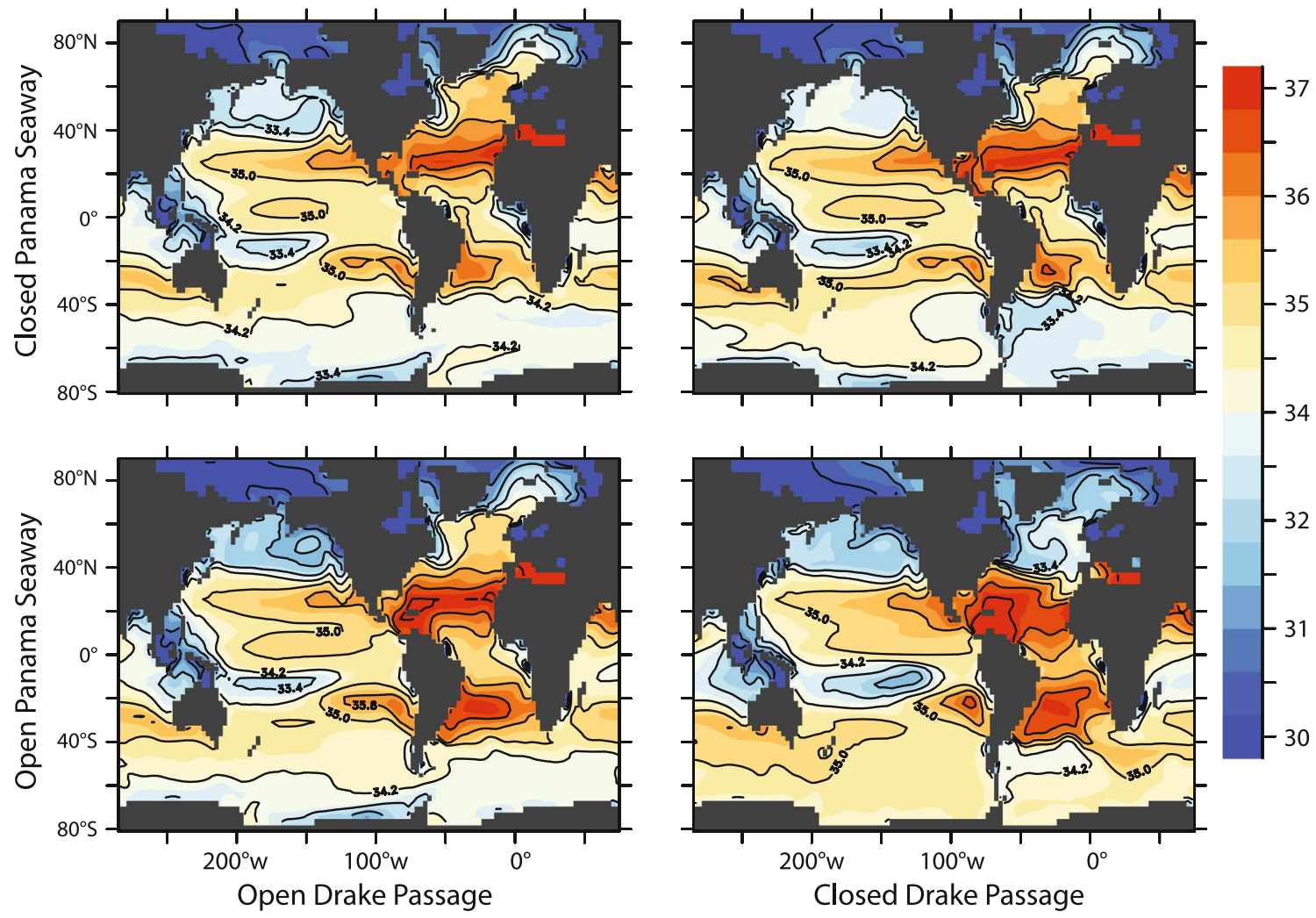

Fig. 7 Simulated sea surface salinities in $\mathrm{g} \mathrm{kg}^{-1}$
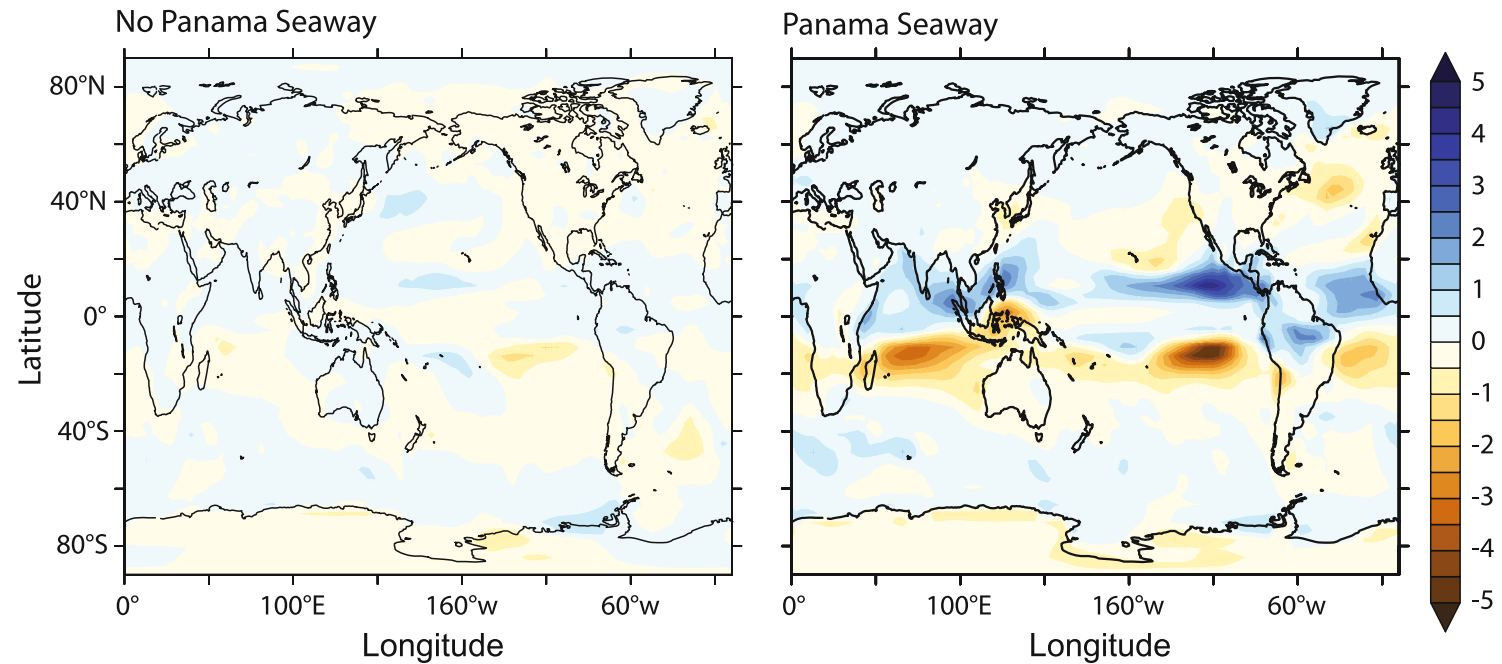

Fig. 8 The effect of Drake Passage on Precipitation Minus Evaporation (PME). The shading indicates PME with Drake Passage open minus PME with Drake Passage closed, without a Panama Seaway (left) and with a Panama Seaway (right) in mm day ${ }^{-1}$

subtropics, can be attributed to changes in evaporation resulting directly from changes in surface atmospheric temperatures (SAT) (Fig. 9). As regions of deep water formation draw in warm subtropical waters, evaporation increases, and although precipitation also increases, there is an overall decrease in PME. The subtropical changes therefore provide a positive evaporative feedback to the circulation changes, enhancing the polar salinity feedback at deep water formation sites (e.g. Rahmstorf 1995).

With these processes in mind, we go on to explain the role of salinity in the contrast between the open and closed Drake Passage simulations in the geologically-relevant 

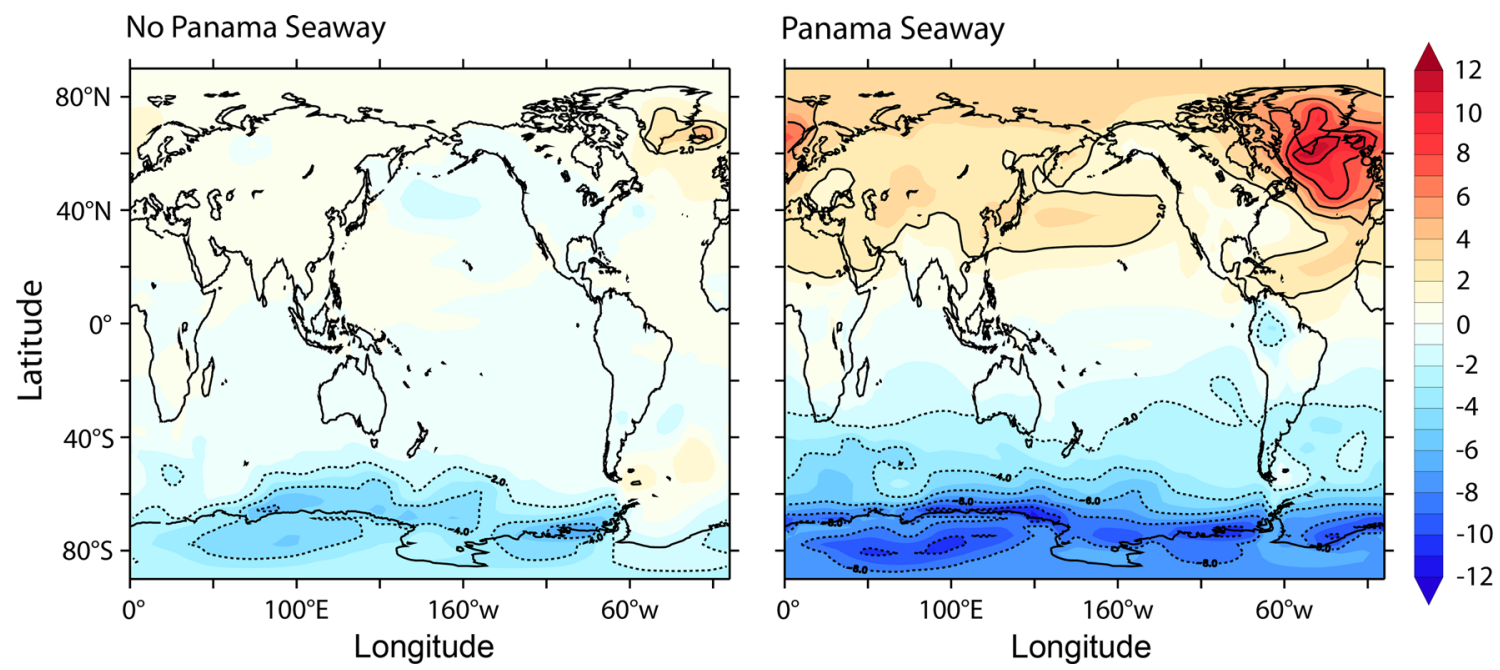

Fig. 9 The effect of the Drake Passage on surface atmospheric temperatures (SAT). The shading indicates SAT with Drake Passage open minus Drake Passage closed, without a Panama Seaway (left) and with a Panama Seaway (right)

case (with a Panama Seaway). With the Drake Passage closed, the strong southern overturning and the extension of the Brazil Current to high southern latitudes keep the Southern Ocean salty. Meanwhile, the absence of NADW formation results in a weak poleward advection of salty subtropical waters, keeping the subpolar Atlantic fresh. With the Drake Passage open, the prevention of the timemean geostrophic flow of surface waters to high southern latitudes cuts off the advection of salty subtropical waters, allowing the positive PME to freshen the Southern Ocean. As a corollary of this, more salt accumulates in the lowlatitude Atlantic to be transported to high northern latitudes. A salinity threshold is reached where NADW becomes dense enough to ventilate the deep ocean, thereby drawing in more subtropical warm salty waters and strengthening ventilation through the polar salinity feedback (which, as shown earlier in this section, includes the evaporative feedback as well as the Stommel feedback). We emphasize that although both a closed Drake Passage and open Panama Seaway push the AMOC to a weaker state, in the model configuration used here, only the two in combination are sufficient to cause a cessation of the AMOC. To test for multiple AMOC equilibria, two additional closed Drake Passage experiments (with and without a Panama Seaway) were run for 900 years, initialized from AMOC states that were opposite to the equilibrated states (i.e. with and without an AMOC, respectively). The results (not shown) simulated a rapid convergence to strong overturning in the case without a Panama Seaway, but suggested that a weak intermediate AMOC state $(5 \mathrm{~Sv})$ can persist for at least 500 years with a Panama Seaway, which may be worth further exploration. It is interesting to compare our results with Zhang et al. (2011) who tested the role of gateways in a range of Eocene-like tectonic configurations, and suggested that if large tropical gateways are open, the AMOC is unable to form. Their results are therefore consistent with the prevention of the AMOC by the combination of a Panama Seaway and closed Drake Passage, and suggest that the Tethys may also have been important, particularly earlier in the Cenozoic and Cretaceous.

A final point worth considering is the degree to which the AMOC strength depends on the depth of the Drake Passage. It has been shown that the history of the Drake Passage opening was a long and tortuous process, rather than a rapid unidirectional deepening (e.g. Lagabrielle et al. 2009). To address this, we conducted a series of five additional experiments with intermediate Drake Passage sill depths (all with a Panama Seaway), resulting in a total of seven Drake Passage sill depths (including the full-depth and zero-depth Passages). The additional experiments were run for only 1,400 years, and thus may not be fully equilibrated. Nonetheless, Fig. 10 shows a strong relationship between the maximum southward transport at $40^{\circ} \mathrm{N}$ and the sill depth of the Drake Passage. Significant NADW starts forming with a sill that is between 300 and $700 \mathrm{~m}$ deep, which appears to reflect the depth of the salty thermocline waters of the South Atlantic Gyre: once the sill depth exceeds this salty layer, the geostrophic barrier prevents their import to the high latitudes, and the Southern Ocean becomes fresher. The existence of an intermediatestrength AMOC in the 700 m-deep Drake Passage simulation suggests that the AMOC would not have abruptly appeared at its modern strength as an abrupt event at a particular threshold depth, but would instead have gradually strengthened as the Drake Passage deepened. Nonetheless, the AMOC is at very close to its modern strength in the 1,500 m-deep simulation, suggesting that the most 


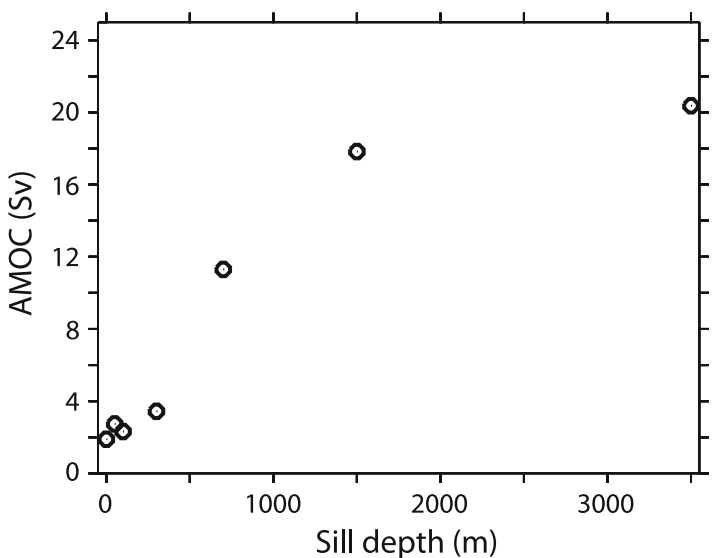

Fig. 10 AMOC strength as a function of the sill depth of the Drake Passage in $\mathrm{Sv}\left(10^{9} \mathrm{~kg} \mathrm{~s}^{-1}\right)$

important depth range lies between 400 and 1,400 m. These results contrast somewhat with Sijp and England (2005) who find the AMOC only when the sill depth is greater than $1,100 \mathrm{~m}$. This difference may be, in part, due to the lack of a Panama Seaway in their simulations. However it is also possible that the critical sill depth varies with the ocean salinity structure and atmospheric forcing. In addition, it is important to bear in mind that other geological events-including changes in $\mathrm{pCO}_{2}$ and tectonic changes elsewhere (e.g. Poore et al. 2011; Stickley et al. 2004; Davies et al. 2001; Abelson et al. 2008)—would have provided additional controls on the AMOC strength over the Cenozoic, modulating the effect of the Drake Passage.

\section{Climate impacts}

\subsection{Temperature changes}

The results discussed above are of relevance to understanding the climate history of the Cenozoic, during which both the Drake Passage and Panama Seaway were tectonically active. During the Eocene, when the Panama Seaway was open and the Drake Passage was closed, Antarctica was warm and unglaciated (Ruddiman 2001). The question of what role the opening of the Drake Passage played in the subsequent Antarctic cooling has been much debated (e.g. Kennett 1977; DeConto and Pollard 2003). The results here would suggest that the Drake Passage opening should indeed have pushed Antarctica to a colder climate, and that this effect has been underestimated by most prior modelling works.

Without the inclusion of a Panama Seaway, the effect of the Drake Passage on surface air temperature (SAT) is up to $4{ }^{\circ} \mathrm{C}$, zonally averaged, over Antarctica. Also, the strengthening of northern overturning results in minor warming over the North Atlantic. The muted temperature response to the Drake Passage in this case is similar to that of prior studies using otherwise-modern boundary conditions (Sijp and England 2004) or Eocene bathymetry that did not include constrictions of tropical gateways (Zhang et al. 2011).

In contrast, with a Panama Seaway, opening the Drake Passage results in a much stronger temperature response. Zonally averaged SAT cool by up to $9{ }^{\circ} \mathrm{C}$ zonally over Antarctica and warm by up to $4{ }^{\circ} \mathrm{C}$ zonally at high northern latitudes. Two factors contribute to this strong response. The first is the thermal isolation of the Southern Ocean, discussed in Sect. 5.2. Second is the establishment of northern overturning, leading to increased northward advection of subtropical waters through increased intergyre exchange and a doubling of the Gulf Stream (Table 2). This can be described as 'heat piracy' from the Southern Hemisphere to the Northern Hemisphere, also discussed in Sect. 5.2.

The latter, more geologically relevant experiment (with a Panama Seaway) results in a maximum zonally-averaged temperature increase that is approximately $2.5 \times$ that simulated by Sijp and England (2004). Furthermore, the change in SAT is much more widespread, and the largest response occurs over Antarctica, unlike the response of Sijp and England (2004) which was concentrated over the South Atlantic and South-East Pacific sectors of the Southern Ocean. The SAT response is similar in magnitude to Sijp et al. (2009a) who, using the same model as Sijp and England (2004), find a greater response to the opening of the Drake Passage when $\mathrm{pCO}_{2}$ is high $(2,000 \mathrm{ppm})$ due to a dramatic retreat of sea ice. Sea ice also provides a feedback to ocean circulation changes in our simulations, but this is amplified by strong atmospheric feedbacks that play a critical role in the large response we observe at preindustrial $\mathrm{pCO}_{2}$, as discussed in Sect. 5.3.

\subsection{Heat transport}

Total meridional heat transport varies by a relatively small amount among the different simulations (Fig. 11). The simulation with the most drastic change in global circulation (with a Panama Seaway and a closed Drake Passage) has greater heat transport to high southern latitudes, less heat transport to high northern latitudes, and more northward cross equatorial transport. Although the changes in total heat transport are small, they conceal significant changes in oceanic heat transports (Fig. 11). This is not surprising, given that changes in ocean heat transport are efficiently compensated by atmospheric heat transport, as shown by theoretical arguments (Stone 1978) and illustrated recently by an idealized water planet model 


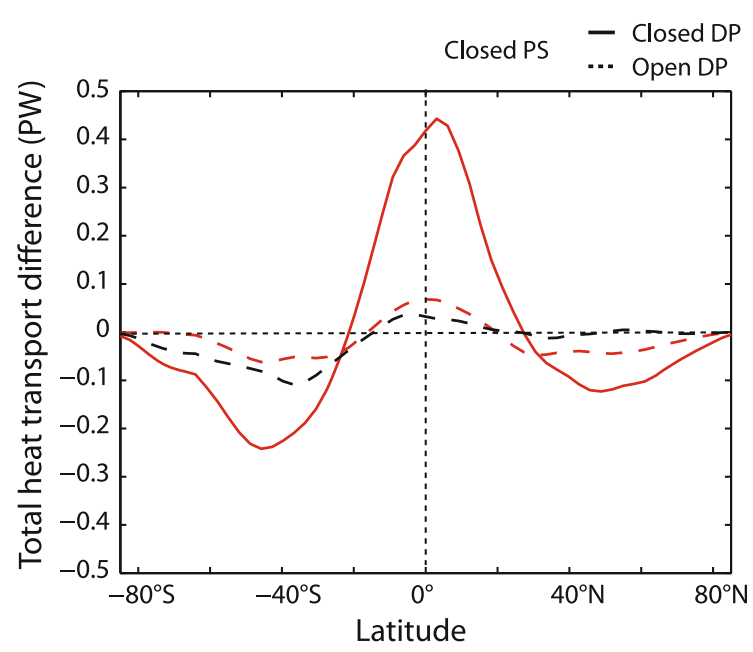

Fig. 11 Total and oceanic meridional heat transports. The left panel shows the zonally and vertically integrated total northward heat transport as differences from the modern land-ocean configuration.

(Enderton and Marshall 2009). Nonetheless, the repartitioning of heat transport between ocean and atmosphere causes a large climate effect (Enderton and Marshall 2009).

Figure 11 also shows the simulated total northward oceanic heat transport. The total oceanic heat transport includes both the shallow circulation and deep overturning circulation. The Atlantic oceanic heat transport is strongly affected by the inter-hemispheric circulation associated with northern overturning, while the Indo-Pacific oceanic heat transport is dominated by the shallow circulation. Overall, the heat transport is strongest in the subtropics where shallow wind driven cells transport heat poleward, while the inter-hemispheric circulation transfers heat from one hemisphere to the other and therefore has the effect of inducing an asymmetry by shifting the heat transport curve vertically.

Open Drake Passage simulations have a weaker heat transport just south of $40^{\circ} \mathrm{S}$ associated with a small timemean geostrophic advection of heat. This changes when the Drake Passage is closed, enabling time-mean geostrophic transport of heat across the Southern Ocean. Without a Panama Seaway, the Drake Passage does not have a large impact on oceanic heat transport, beyond the effect of this geostrophic barrier. In contrast, with a Panama seaway, much more significant changes in oceanic heat transport occur, because the inter-hemispheric circulation leads to a strong vertical shift of the heat transport curve with stronger poleward heat transport in the Northern Hemisphere and weaker poleward transport in the Southern Hemisphere. Kennett (1977)'s idea of 'thermal isolation' is therefore only part of the story: the other part is the role of ACC's development in bringing on the northern overturning, which leads to a much greater impact on oceanic heat transport.

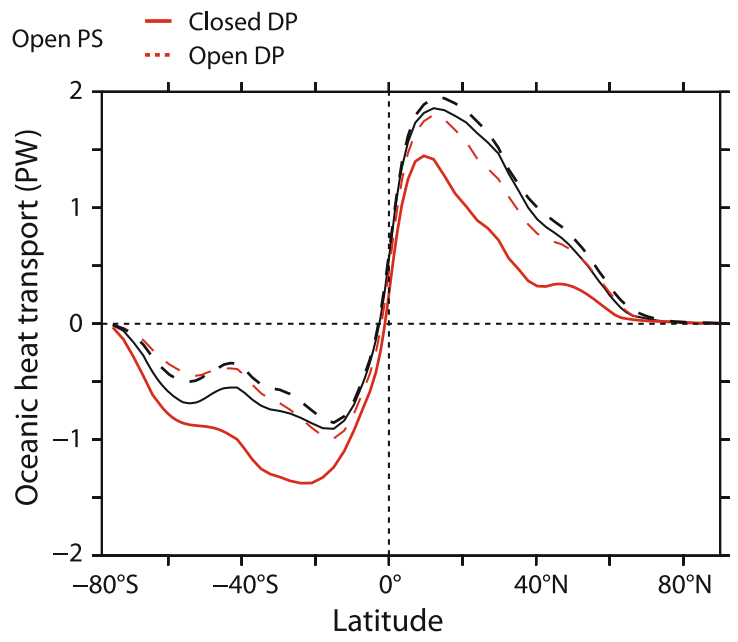

The right panel shows the zonally and vertically integrated northward oceanic heat transports for all four gateway configurations. All heat transports are in in Petawatts $\left(10^{15} \mathrm{~W}\right)$

\subsection{Atmospheric response}

\subsubsection{ITCZ shift}

With a Panama Seaway, the Drake Passage has a large influence on the tropical atmospheric circulation, including the position of the Inter-Tropical Convergence zone (ITCZ), as shown by the atmospheric meridional mass transport (Fig. 12). With an open Drake Passage, the ITCZ is 'split' (see Fig. 8), a nearly-universal deficiency of coupled models (Bellucci et al. 2010). A closed Drake Passage leads to the intensification of the southern ITCZ and the reduction of the northern one, shifting overall the ITCZ southward, to the warmer hemisphere. The northern Hadley cell expands and the southern one shrinks making energy from the southern tropics available for transport to northern mid and high latitudes to compensate for the weakening in inter-hemispheric oceanic heat transport resulting from the shutdown of northern overturning.

Analogous bipolar changes in temperature are observed in records documenting the last glacial period. Abrupt cooling in the North Atlantic followed by more gradual warming in the Southern Ocean (Dansgaard et al. 1993) is also thought to have been caused by variation in the AMOC strength (Broecker et al. 1985; Alley 2007), generally attributed to freshwater forcing due to iceberg discharge. Evidence for meridional displacements of the ITCZ during the rapid temperature variations of the North Atlantic (Peterson et al. 2000; Dykoski et al. 2005; Wang et al. 2005; Wang et al. 2006) suggest a strong teleconnection between the extra-tropical changes in temperature and the tropics. Broccoli et al. (2006) indeed showed that 

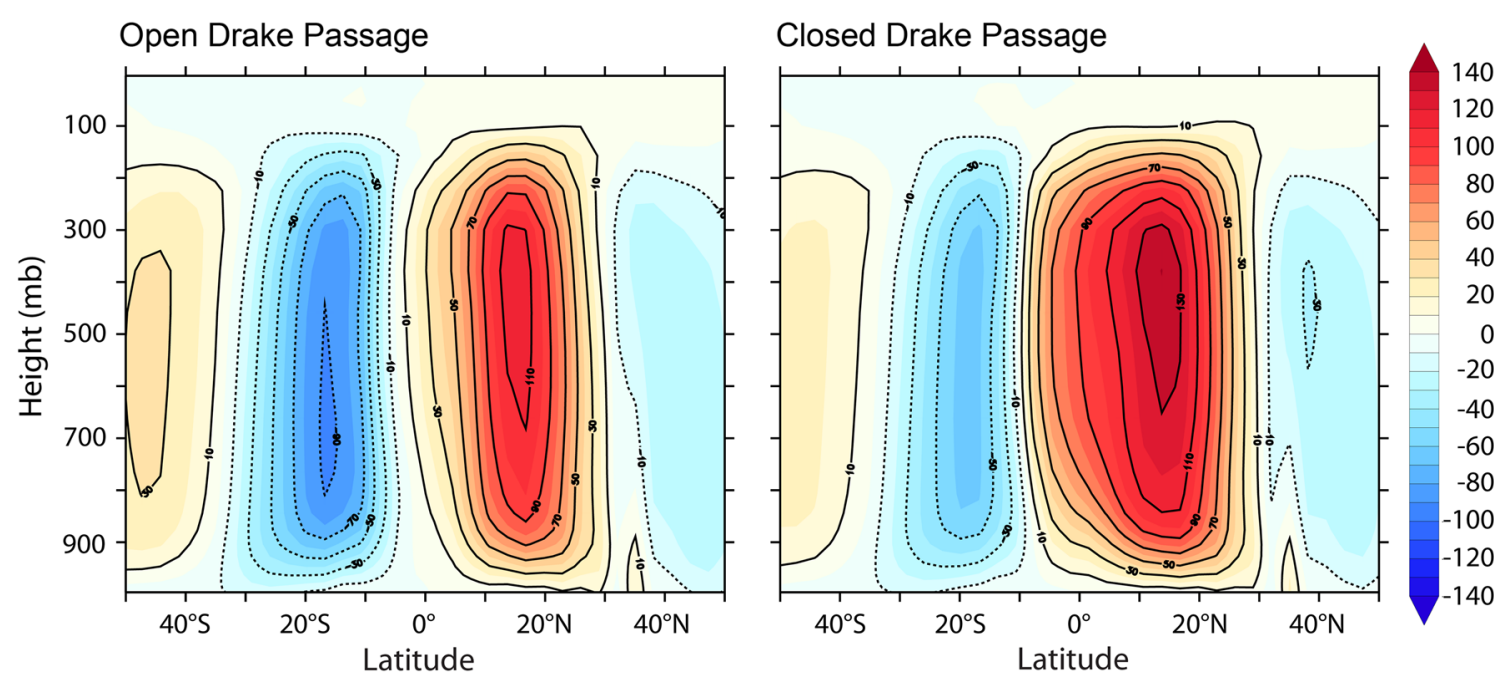

Fig. 12 Zonally integrated meridional atmospheric transport with a Panama Seaway for both an open (left) and closed Drake Passage (right) in $10^{9} \mathrm{~kg} \mathrm{~s}^{-1}$

simulated asymmetric inter-hemispheric heating at high latitudes results in the shift of the ITCZ towards the heated hemisphere.

The analogous ITCZ shift observed here demonstrates that the tight coupling between cross-equatorial oceanic heat transport and global atmospheric circulation can be an important response to tectonic forcing, as well as freshwater forcing. This may have played a role in a number of past climate changes.

\subsubsection{Atmospheric radiative feedback}

The strong atmospheric temperature response to the presence of Drake Passage, particularly in the experiments with a Panama Seaway, reflects an enhancement of the circulation changes by radiative feedbacks. Following Kang et al. (2009), we analyze the radiative feedback in terms of changes in cloud cover and height (high and low) as well as changes in short-wave and long-wave cloud radiative forcing (CRF) defined as the flux at the top of the atmosphere (TOA) minus the same flux calculated for clear-sky conditions. As seen from Fig. 13 the change in the net radiation at the TOA acts to enhance the temperature response in both hemispheres. The CRF dominates the overall change in the radiative budget, generally acting as a positive feedback on ocean temperature. The clear-sky response, in contrast, generally acts as a negative feedback over mid and high latitudes, reflecting the long-wave adjustment to changing surface temperatures. The clear sky response over the tropics is the result of the ITCZ shift resulting in changes in water vapor (not shown here). Meanwhile, the change in CRF over mid-latitude results from increased low cloud cover in the Southern Hemisphere and reduced low cloud cover in the Northern
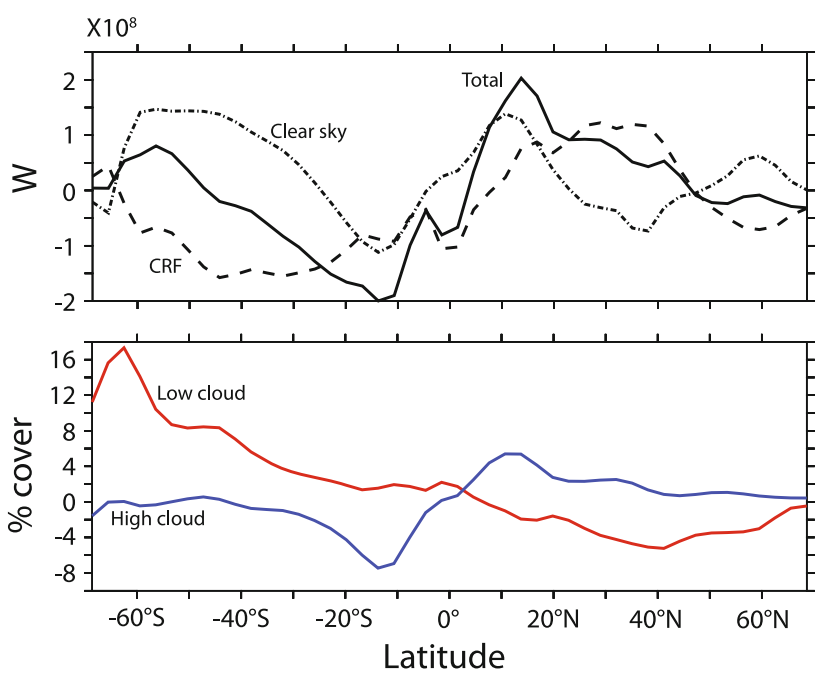

Fig. 13 Radiative feedbacks to the presence of the Drake Passage, with a Panama Seaway. All curves are calculated as Open Drake Passage minus closed Drake Passage. Top panel: radiation at the Top Of the Atmosphere (TOA), including total, clear sky and cloud radiative forcing $(\mathrm{CRF})$. The cloud radiative component is defined as the total flux minus the same flux calculated for clear-sky conditions. Bottom panel: changes in cloud cover at the two cloud heights

Hemisphere. In the tropics, changes in the CRF result from a northward shift of high clouds, which produce a net warming, associated with the ITCZ shift.

As explained by Kang et al. (2009), changes in surface air temperatures resulting from the presence of northern overturning will destabilize the atmosphere in the warmer northern hemisphere, resulting in decreased shallow atmospheric convection (and hence fewer low clouds), and stabilize the atmosphere in the cooler southern hemisphere, leading to increased shallow convection (more low clouds). This general mechanism is consistent with Klein and 
Hartmann (1993), who showed that observed low-cloud amount increases with the static stability of the lower troposphere at the seasonal timescale, and Norris and Leovy (1994) who found significant negative correlation between low cloud amount and SST over the mid-latitude ocean at the inter-annual timescale.

The positive radiative feedback triggered by the northern overturning can therefore be understood as reflecting changes in low-cloud cover, resulting from the bipolar changes in SST, combined with a redistribution of high clouds linked with the migration of the ITCZ.

\section{Conclusion}

Two major results arise from this analysis of the ocean circulation and climate impacts of the Drake Passage. First, the Panama Seaway has a major influence on how the Drake Passage affects ocean circulation, due to its impact on the Pacific-Atlantic exchange of freshwater, as well as the dynamical impact on the southward transport of salty subtropical waters by the Brazil current. These circulation changes alter the freshwater balance of both the North Atlantic and circum-Antarctic, changing the ability of these regions to ventilate the deep ocean. Because of its importance, simulations that do not include the Panama Seaway are of questionable relevance to any time period in which the seaway was open.

Second, atmospheric dynamics and cloud feedbacks amplify the climate effect of Drake Passage, particularly if the AMOC is subject to large changes due to other tectonic or radiative boundary conditions. This has led to a large underestimate of the Drake Passage climate impact in models that do not resolve atmospheric dynamics and clouds (e.g. Sijp and England 2009). In the model, the ITCZ shifts between hemispheres in conjunction with changes in the AMOC, following the warmer hemisphere, changing the distribution of precipitation and cross-equatorial heat transport. This model prediction, which is analogous to the changes observed during Dansgaard-Oeschger cycles of the Quaternary, may be testable with proxy records.

The importance of the salty Brazil current, which exists with a Panama Seaway at less than $1,000 \mathrm{~m}$ depth, is consistent with the critical depth range for the Drake Passage lying between 400 and 1,000 m. At depths less than this, the Antarctic receives plenty of salty waters, and beyond depths greater than this, the supply of salt has already been extinguished. Thus, if the Drake Passage alternately shoaled and deepened through the mid-Cenozoic (Lagabrielle et al. 2009), it may have led to a tectonically-moderated 'bi-polar see-saw', that alternately cooled and warmed the Northern and Southern hemispheres, and could have played a role in the bumpy climate history of the Oligocene.
In summary, a global coupled model, with a full atmospheric model and no flux adjustments, shows a considerably higher climate sensitivity to the presence of the Drake Passage than most prior model studies, particularly when the Panama Seaway is also open. This suggests that the importance of tectonic gateways to climate has been frequently underestimated (e.g. DeConto and Pollard 2003). Other factors were doubtless of great importance in the climate history of the Cenozoic, such as gradual changes in $\mathrm{pCO}_{2}$, changes in land-based ice sheets, differences in vegetation patterns, and other changes in ocean basin shape not explored here. In particular, the presence of high atmospheric $\mathrm{pCO}_{2}$ may have amplified (Sijp et al. (2009a)) or damped the impact of both these tectonic gateways (Lefebvre et al. 2012). Nevertheless, our results are consistent with the idea that Cenozoic cooling of Antarctica was promoted by the opening of the Drake Passage.

Acknowledgments This work was supported by the Canadian Institute for Advanced Research (CIFAR) Earth System Evolution Program, and by the Natural Sciences and Engineering Research Council of Canada (NSERC). Compute Canada and Scinet provided the computational resources.

\section{References}

Abelson M, Agnon A, Almogi-Labin A (2008) Indications for control of the Iceland plume on the "greenhouse-icehouse" climate transition. Earth Planet Sci Lett 265(333):333

Adcroft A, Hill C, Marshall J (1997) Representation of topography by shaved cells in a height coordinate ocean model. Mon Weather Rev 125(9):2293-2315

Alley RB (2007) Wally was right: predictive ability of the North Atlantic "conveyor belt" hypothesis for abrupt climate change. Annu Rev Earth Planet Sci 35(1):241-272

Bellucci A, Gualdi S, Navarra A (2010) The double-ITCZ syndrome in coupled general circulation models: the role of large-scale vertical circulation regimes. J Clim 23:1127-1145

Broccoli AJ, Dahl KA, Stouffer RJ (2006) Response of the ITCZ to northern hemisphere cooling. Geophys Res Lett 33(1):L01702

Broecker W (1991) The great ocean conveyor. Oceanography 4(2):79-89

Broecker WS, Peteet DM, Rind D (1985) Does the ocean-atmosphere system have more than one stable mode of operation? Nature 315:21-25

Carmack EC (2007) The alpha/beta ocean distinction: A perspective on freshwater fluxes, convection, nutrients and productivity in high-latitude seas. Deep Sea Res Part II Top Stud Oceanogr 54(23-26):2578-2598

Cristini L, Grosfeld K, Butzin M, Lohmann G (2012) Influence of the opening of the Drake Passage on the Cenozoic Antarctic Ice Sheet: a modeling approach. Palaeogeogr Palaeoclimatol 339(34):66-73

Dansgaard W, Johnsen SJ, Clausen HB (1993) Evidence for general instability of past climate from a 250-kyr ice-core record. Nature 364:218-220

Davies R, Cartwright J, Pike J, Line C (2001) Early Oligocene initiation of North Atlantic deep water formation. Nature 410(6831):917-920 
DeConto R, Pollard D (2003) Rapid Cenozoic glaciation of Antarctica induced by declining atmospheric $\mathrm{CO}_{2}$. Nature 421(6920): 245-249

Delworth T, Broccoli A, Rosati A, Stouffer R, Balaji V, Beesley J, Cooke W, Dixon K, Dunne J, Dunne K, Durachta J, Findell K, Ginoux P, Gnanadesikan A, Gordon C, Griffies S, Gudgel R, Harrison M, Held I, Hemler R, Horowitz L, Klein S, Knutson T, Kushner P, Langenhorst A, Lee H, Lin S, Lu J, Malyshev S, Milly P, Ramaswamy V, Russell J, Schwarzkopf M, Shevliakova E, Sirutis J, Spelman M, Stern W, Winton M, Wittenberg A, Wyman B, Zeng F, Zhang R (2006) GFDL's CM2 global coupled climate models. Part I: formulation and simulation characteristics. J Clim 19(5):643-674

Dijkstra HA, Weijer W, Neelin JD (2003) Imperfections of the threedimensional thermohaline circulation: hysteresis and uniquestate regimes. J Phys Oceanogr 33:2796-2814

Dunne JP, John JG, Adcroft AJ, Griffies SM, Hallberg RW, Shevliakova E, Stouffer RJ, Cooke W, Dunne KA, Harrison MJ, Krasting JP, Malyshev SL, Milly PCD, Phillipps PJ, Sentman LT, Samuels BL, Spelman MJ, Winton M, Wittenberg AT, Zadeh N (2012) GFDL's ESM2 global coupled climatecarbon earth system models. Part I: physical formulation and baseline simulation characteristics. J Clim 25(19):6646-6665

Dykoski CA, Edwards RL, Cheng H, Yuan D (2005) A highresolution, absolute-dated Holocene and deglacial Asian monsoon record from Dongge Cave, China. Earth Planet Sci Lett 233(1-2):71-86

Enderton D, Marshall J (2009) Explorations of atmosphere-ocean-ice atmosphere-ocean-ice climates on an aquaplanet and their meridional energy transports. J Atmos Sci 66(6):1593-1611

Ferreira D, Marshall J, Campin JM (2010) Localization of deep water formation: role of atmospheric moisture transport and constraints on ocean circulation. J Clim 23(6):1456-1476

Galbraith ED, Kwon EY, Gnanadesikan A, Rodgers KB, Griffies SM, Bianchi D, Sarmiento JL, Dunne JP, Simeon J, Slater RD, Wittenberg AT, Held IM (2011) Climate Variability and Radiocarbon in the CM2Mc Earth System Model. Journal of Climate 24(16):4230-4254

Gent P, Mcwilliams J (1990) Isopycnal mixing in ocean circulation models. J Phys Oceanogr 20(1):150-155

Gnanadesikan A (1999) A simple theory of the pycnocline and overturning. Science 283(5410):2077-2079

Godfrey JS (1989) A sverdrup model of the depth-integrated flow from the world ocean allowing for circulation around islands. Geophys Astrophys Fluid Dyn 45:89-112

Kang SM, Frierson DMW, Held IM (2009) The tropical response to extratropical thermal forcing in an idealized GCM: the importance of radiative feedbacks and convective parameterization. J Atmos Sci 66(9):2812-2827

Kennett J (1977) Cenzoic evolution of Antarctic glaciation, circumArctic ocean, and their impact on global paleoceanography. J Geophys Res-Oc Atm 82(27):3843-3860

Klein SA, Hartmann DL (1993) The seasonal cycle of low stratiform clouds. J Clim 6(8):1587-1606

Kuhlbrodt T, Griesel A, Montoya M, Levermann A, Hofmann M, Rahmstorf S (2007) On the driving processes of the Atlantic meridional overturning circulation. Rev Geophys 45(2):RG2001

Lagabrielle Y, Goddéris Y, Donnadieu Y, Malavieille J, Suarez M (2009) The tectonic history of Drake Passage and its possible impacts on global climate. Earth Planet Sci Lett 279:197-211

Lawver L, Gahagan L (2003) Evolution of Cenozoic seaways in the circum-Antarctic region. Palaeogeogr Palaeoclimatol 198:11-37

Lefebvre V, Donnadieu Y, Sepulchre P, Swingedouw D, Zhang Z (2012) Deciphering the role of southern gateways and carbon dioxide on the onset of the Antarctic Circumpolar Current. Paleoceanography 27:1-9
Livermore R, Nankivell A, Morris GEP (2005) Paleogene opening of Drake Passage. Earth Planet Sci Lett 236(1-2):459-470

Livermore R, Hillenbrand C, Meridith M, Eagles G (2007) Drake Passage and Cenozoic climate: an open and shut case? Geochem Geophys Geosyst 8(1):1-11

Lumpkin L, Spear K (2007) Global ocean meridional overturning. J Phys Oceanogr 37:2550-2562

Lunt DJ, Valdes PJ, Haywood A, Rutt IC (2008) Closure of the Panama Seaway during the Pliocene: implications for climate and Northern Hemisphere glaciation. Clim Dyn 30(1):1-18

Maier-Reimer E, Mikolajewicz U, Crowley TJ (1990) Ocean general circulation model sensitivity experiment with an open Central American Isthmus. Paleoceanography 5(3):349-366

Marshall J, Speer K (2012) Closure of the meridional overturning circulation through Southern Ocean upwelling. Nat Geosci 5(3): $171-180$

Mikolajewicz U, Crowley T (1997) Response of a coupled ocean/ energy balance model to restricted flow through the central American isthmus. Paleoceanography 12(3):429-441

Mikolajewicz U, Maier-Reimer E, Crowley TJ (1993) Effect of Drake Passage and Panamian gateways on the circulation of an ocean model. Paleoceanography 8:409-426

Murdock T, Weaver A, Fanning A (1997) Paleoclimatic response of the closing of the Isthmus of Panama in a coupled oceanatmosphere model. Geophys Res Lett 24(3):253-256

Nikurashin M, Vallis G (2012) A theory of the interhemispheric meridional overturning circulation and associated stratification. J Phys Oceanogr 42:1652-1667

Nisancioglu K, Raymo M, Stone P (2003) Reorganization of miocene deep water circulation in response to the shoaling of the Central American Seaway. Paleoceanography 18(1):1006

Nong G, Najjar R, Seidov D, Peterson W (2000) Simulation of ocean temperature change due to the opening of Drake Passage. Geophys Res Lett 27(17):2689-2692

Norris JR, Leovy CB (1994) Interannual variability in stratiform cloudiness and sea surface temperature. J Clim 7:1915-1925

Palter JB, Sarmiento JL, Gnanadesikan A, Simeon J, Slater RD (2010) Fueling export production: nutrient return pathways from the deep ocean and their dependence on the meridional overturning circulation. Biogeosciences 7:3549-3568

Peterson LC, Haug GH, Hughen KA, Röhl U (2000) Rapid Changes in the Hydrologic Cycle of the tropical Atlantic during the last glacial. Science 290:1947-1950

Poore H, White N, Maclennan J (2011) Ocean circulation and mantle melting controlled by radial flow of hot pulses in the Iceland plume. Nat Geosci 4:558-561

Rahmstorf S (1995) Bifurcation of the Atlantic thermohaline circulation in response to changes in the hydrological cycle. Nature 378:145-149

Ruddiman WF (2001) Earth's climate, past and future. W.H. Freeman and Company, New York

Russell JL, Stouffer RJ, Dixon KW (2006) Intercomparison of the Southern Ocean Circulations in IPCC coupled model control simulations. J Clim 19:4560-4575

Scher HD, Martin EE (2006) Timing and climatic consequences of the opening of Drake Passage. Science 312:428-330

Scher HD, Martin EE (2008) Oligocene deep water export from the North Atlantic and the development of the Antarctic Circumpolar Current examined with neodymium isotopes. Paleoceanography 23(1):PA1205

Schneider B, Schmittner A (2006) Simulating the impact of the Panamanian seaway closure on ocean circulation, marine productivity and nutrient cycling. Earth Planet Sci Lett 246(3-4):367-380

Sijp W, England M (2005) Role of the Drake Passage in controlling the stability of the ocean's Thermohaline circulation. J Clim 18(12):1957-1966 
Sijp WP, England MH (2004) Effect of the Drake Passage throughflow on global climate. J Phys Oceanogr 34(5):12541266

Sijp WP, England MH (2009) Atmospheric moisture transport moderates climatic response to the opening of Drake Passage. J Clim 22(9):2483-2493

Sijp WP, England MH, Toggweiler JR (2009) Effect of Ocean gateway changes under greenhouse warmth. J Clim 22(24): 6639-6652

Sijp WP, England MH, Toggweiler JR (2009) Effect of ocean gateway changes under greenhouse warmth. J Clim 22(24): $6639-6652$

Simmons HL, Jayne SR, Laurent LCS, Weaver AJ (2004) Tidally driven mixing in a numerical model of the ocean general circulation. Ocean Model 6:245-263

Stickley C, Brinkhuis H, Schellenberg S, Sluijs A, Rohl U, Fuller M, Grauert M, Huber M, Warnaar J, Williams G (2004) Timing and nature of the deepening of the Tasmanian Gateway. Paleoceanography 19(4):PA4027

Stommel H (1961) Thermohaline convection with two stable regimes of flow. Tellus 13(2):224-230

Stone PH (1978) Constraints on dynamical transports of energy on a spherical planet. Dyn Atmos Oceans 2(2):123-139

Talley LD (2008) Freshwater transport estimates and the global overturning circulation: Shallow, deep and throughflow components. Prog Oceanogr 78:257-303

Thomas D, Bralower T (2003) Neodymium isotopic reconstruction of late paleocene-early eocene thermohaline circulation. Earth Planet Sci Lett 209(3-4):309-322
Thomas DJ, Lyle M, More TC, Rea DK (2008) Paleogene deepwater mass composition of the tropical Pacific and implications for thermohaline circulation in a greenhouse world. Geochem Geophys Geosyst 9(2):1-13

Tigchelaar M, von der Heydt AS, Dijkstra HA (2011) A new mechanism for the two-step $\delta 18 \mathrm{O}$ signal at the EoceneOligocene boundary. Clim Past 7:235-247

Toggweiler J, Bjornsson H (2000) Drake Passage and palaeoclimate. J Quat Sci 15(4):319-328

Toggweiler J, Samuels B (1995) Effect of Drake Passage on the global thermohaline circulation. Deep Sea Res Part I 42(4)

Via RK, Thomas DJ (2006) Evolution of Atlantic thermohaline circulation: early oligocene onset of deep-water production in the North Atlantic. Geology 34(6):441-444

Wang X, Edwards ASARL, Cheng H, Ito E (2006) Interhemispheric anti-phasing of rainfall during the last glacial period. Quat Sci Rev 25(23-24):3391-3403

Wang Y, Cheng H, Edwards RL, He Y, Kong X, An Z, Wu J, Kelly MJ, Dykoski CA, Li X (2005) The Holocene Asian monsoon: links to solar changes and North Atlantic climate. Science 308:854-857

Warren B (1983) Why is no deep water formed in the North Pacific. J Mar Res 41:327-347

Zhang Z, Yan Q, Wang H (2010) Has the Drake Passage played an essential role in the Cenozoic Cooling. Atmos Ocean Sci Lett 3(5):288-292

Zhang Z, Nisancioglu KH, Flatøy F, Bentsen M, Bethke I, Wang H (2011) Tropical seaways played a more important role than high latitude seaways in Cenozoic cooling. Clim Past 7(3):801-813 